\title{
Genes within the serotonergic system are differentially expressed in
} human brain

\author{
Karen Sugden ${ }^{1}$, Ales Tichopad ${ }^{2}$, Nadeem Khan ${ }^{3}$, Ian W Craig' and \\ Ursula M D'Souza*1
}

Address: ${ }^{1}$ MRC Social, Genetic and Developmental Psychiatry (SGDP) Centre, Institute of Psychiatry, King's College London, UK, ${ }^{2}$ Physiology Weihenstephan, Center of Life and Food Sciences (ZIEL), Technical University of Munich, 85350 Freising, Germany and ${ }^{3}$ Department of Neuropathology, Brain Bank, Institute of Psychiatry, King's College London, UK

Email: Karen Sugden - K.Sugden@iop.kcl.ac.uk; Ales Tichopad - ales@tichopad.de; Nadeem Khan -ny.khan1@virgin.net; Ian W Craig - I.Craig@iop.kcl.ac.uk; Ursula M D'Souza* - spjgumd@iop.kcl.ac.uk

* Corresponding author

Published: 15 May 2009

BMC Neuroscience 2009, 10:50 doi:10.1 |86//47|-2202-10-50
Received: 31 October 2008

Accepted: 15 May 2009

This article is available from: http://www.biomedcentral.com/I47I-2202/10/50

(C) 2009 Sugden et al; licensee BioMed Central Ltd.

This is an Open Access article distributed under the terms of the Creative Commons Attribution License (http://creativecommons.org/licenses/by/2.0), which permits unrestricted use, distribution, and reproduction in any medium, provided the original work is properly cited.

\begin{abstract}
Background: Serotonin is an important neurotransmitter with wide-ranging functions throughout the central nervous system. There is strong evidence to suggest that regulation of serotonergic gene expression might be related to genetic variability, and several studies have focused on understanding the functional effects of specific polymorphisms within these genes on expression levels. However, the combination of genotype together with gender and brain region could have an overall effect on gene expression. In this study, we report expression patterns of five serotonergic genes (TPHI, TPH2, 5-HT2A, 5-HT2C, 5-HTT) in seven different human post-mortem brain regions (superior frontal gyrus, superior temporal gyrus, striatum, cerebellum, hippocampus, midbrain and thalamus) using TaqMan ${ }^{\mathrm{TM}}$ real-time quantitative PCR. In addition, the effect of genotype and gender on their expression levels was determined.
\end{abstract}

Results: The data revealed that mRNA from the five genes investigated was detected in all brain regions and showed an overall significant difference in expression levels. Furthermore, the expression of $5-H T 2 C, 5-H T 2 A$ and TPH2 was found to be significantly different between the various brain regions. However, neither gender nor genotype showed significant effects on the expression levels of any of the genes assayed. Interestingly, TPHI and TPH2 were expressed in all brain regions similarly except for within the striatum and cerebellum, where TPHI was expressed at a significantly higher level than TPH2.

Conclusion: The effect of brain region has a greater influence on serotonergic gene expression than either genotype or gender. These data add to the growing body of evidence that effects of functional polymorphisms on gene expression in vitro are not observed ex vivo, and provide information that will aid in the design of expression studies of the serotonergic gene system within human post-mortem brain. 


\section{Background}

Serotonin (5-HT) is an important neurotransmitter found in neurons which project to various areas in the central nervous system. Consequently it is associated with several physiological mechanisms [1]. It mediates cellular effects through several proteins that are involved with its neurotransmission, synthesis, metabolism and membrane reuptake [2,3]. Disturbances in brain serotonergic systems result in a range of phenotypes such as depression, suicide and anxiety disorders [3-5].

Many functional imaging and binding studies have demonstrated that these disorders can, in part, be explained by differential binding and/or function of components of the serotonergic system such as receptors and enzymes. However, whether these observed differences correspond to differences in gene expression is largely unknown. Regulation of expression occurs via several different processes, but most studies have focused on genetic variation as a potential factor [6]. However, although many polymorphic variations have been demonstrated to elicit changes in expression in vitro (studies in cell cultures), little information on their role in ex vivo investigations using human post-mortem brain tissue exists. Furthermore, despite much attempt to determine a link between 5-HT pathway gene polymorphisms and disease phenotype, few consistent findings have been made including the promoter polymorphism in the 5-HTT gene and anxiety-related traits $[7,8]$. Although there are many methodological and biological reasons for this, one explanation might be that differential regulation could be elicited via additional factors such as tissue type and gender as well as background genetic variation.

Some of the most widely studied serotonergic genes include tryptophan hydroxylase 1 and 2 (TPH1 and TPH2; serotonin synthesis), serotonin receptors $2 \mathrm{~A}$ and $2 \mathrm{C}$ (5HT2A and 5-HT2C; post-synaptic receptors) and serotonin transporter (5-HTT, serotonin re-uptake). TPH is the rate-limiting enzyme in the biosynthetic pathway of serotonin and thus has a major function in regulating the serotonergic system. Studies in mice have revealed the existence of two isoforms of the gene termed as TPH1 and TPH2, with rat and human homologues of the second isoform also cloned [9]. Although the discovery of TPH2 is relatively recent, evidence has emerged in support of its expression in human post-mortem brain. Firstly, TPH2 expression was observed in specific post-mortem brain regions including cortex, thalamus, hippocampus, amygdala and hypothalamus [10]. Secondly, differential expression of TPH1 and TPH2 genes in various post-mortem brain regions has been demonstrated, with TPH2 expression being significantly higher in raphe nuclei [10]. However, TPH1 expression was found to be significantly higher than that of TPH2 in hypothalamus and amygdala.
The functional effects of genetic variation in TPH1 and TPH2 genes have had little investigation. However, there is evidence that in the TPH1 gene the TGT haplotype of 3 SNPs (T-1607C, G-1066A, T-346G) within the 5'regulatory region repressed transcriptional activity in human cell lines [11]. Similarly, [12] have demonstrated that a haplotype of 3 SNPs within the TPH2 promoter (G-703T, T-473A, and A90G) also influenced transcription in rat and human cell lines, the TTA haplotype resulting in reduced gene expression.

5-HT2A and 5-HT2C receptors are both expressed postsynaptically on serotonergic neurons. 5-HT2A receptors are found mainly in the cortex and hippocampus $[13,14]$ whilst 5-HT2C receptors are found in greatest density in the choroid plexus, although they are also located in other brain regions such as the prefrontal cortex $[15,16]$. It has been suggested that there is some similarity between the neuronal distribution of 5-HT2A binding sites and 5HT2A mRNA [14]. More recently, quantitative RT-PCR has revealed more abundant 5-HT2A mRNA in the cortex compared with the hippocampus in rat brain [17]. Interestingly, 5-HT2A receptor density has been shown to be under gender-specific influence, where men demonstrated significantly higher binding capacity of receptors than women [18].

There are a number of polymorphisms in the 5-HT2A gene, some of which have been investigated in terms of their effect on transcription, particularly the two highlylinked SNPs T102C and A-1436G. Both the A and G alleles of the latter have significant basal promoter activity in HeLa cells [19]. More recently, the transcriptional activity of the $\mathrm{G}$ allele was found to be significantly lower than the A allele when the more downstream of the two promoters was included in the constructs and in the presence of an enhancer region [20]. This effect was only observed in endogenous 5-HT2A expressing cell-lines, suggesting the presence of cell specific transcription factors is necessary to elicit this functional effect. However, no differences were found in allele-specific expression of the A-1436G SNP in human post-mortem brain tissue [21].

Four variants within the promoter of the 5-HT2C gene have been identified and their influence on gene expression investigated [22]. Two haplotypes each consisting of a particular allele of an upstream GTn microsatellite (Z-6) were found to increase expression of the gene relative to the wild-type. Furthermore, this effect was not cell-specific, suggesting that it would be present in any tissue expressing 5-HT2C.

5-HTT is responsible for re-uptake of serotonin at the presynaptic neuron, and is the site of action of several selective serotonin reuptake inhibitors and tricyclic antidepres- 
sants. The gene is expressed widely in the brain with highest expression detected in the dorsal raphe nuclei [23]. One of the most documented variants within 5-HTT is the serotonin transporter-linked polymorphic region (5-HTTLPR), a repeat region which exists as two common alleles, the short allele ('S') and long ('L'). There is evidence that this polymorphic region has functional significance, where in human carcinoma cells and lymphoblastoid cells, the L allele confers higher activity than the S allele [24]. More recently, it has been shown that the $\mathrm{S}$ and $\mathrm{L}$ alleles are themselves variable in that SNPs occur within their repeating units [25]. Another functional VNTR (variable number of tandem repeat) within intron 2 of the 5-HTT gene has revealed differential enhancer activities in the mouse embryo [26] and embryonic stem cells [27].

Here, we focused on first determining whether the mRNA expression levels of TPH1, TPH2, 5-HT2A, 5-HT2C and 5$H T T$ genes are affected by brain region, genotype or gender. Real-time quantitative PCR (qPCR) was utilised to determine the relative expression levels for these genes in seven different human post-mortem brain regions. The investigated polymorphisms are described above and are located either within, or close to, the postulated promoter region of the genes of interest suggesting a plausible functional effect. Given the extensive literature concerning the significance of TPH1 in disease aetiology, and the potential complication of the existence of its paralogue TPH2, the second aim was to compare the levels of expression of the two loci in the various brain regions.

\section{Results}

All genes assayed were expressed in all brain regions tested, and these data are represented in Figure 1. Preliminary analyses of the relative expression across all brain regions (grouping individual $2^{-\Delta \mathrm{Ct}}$ values) showed an overall significant difference in the mRNA levels of the five genes investigated $(\mathrm{p}<0.001 \mathrm{~F}=108.782) .5-H T 2 \mathrm{~A}$ has an overall highest expression level, whereas 5-HTT had the lowest expression level.

\section{Effect of gender on gene expression}

Gender did not have any significant effect on the overall brain expression levels of the genes we assayed in this sample (data combined for all seven brain regions). However, expression of most genes was generally higher in males than in females (see Figure 2). Furthermore, there were no significant gender differences on gene expression levels within any of the brain regions we assayed (data not shown).

\section{Effect of brain region on gene expression}

There were significant differences in expression levels of three genes within different brain regions. These genes

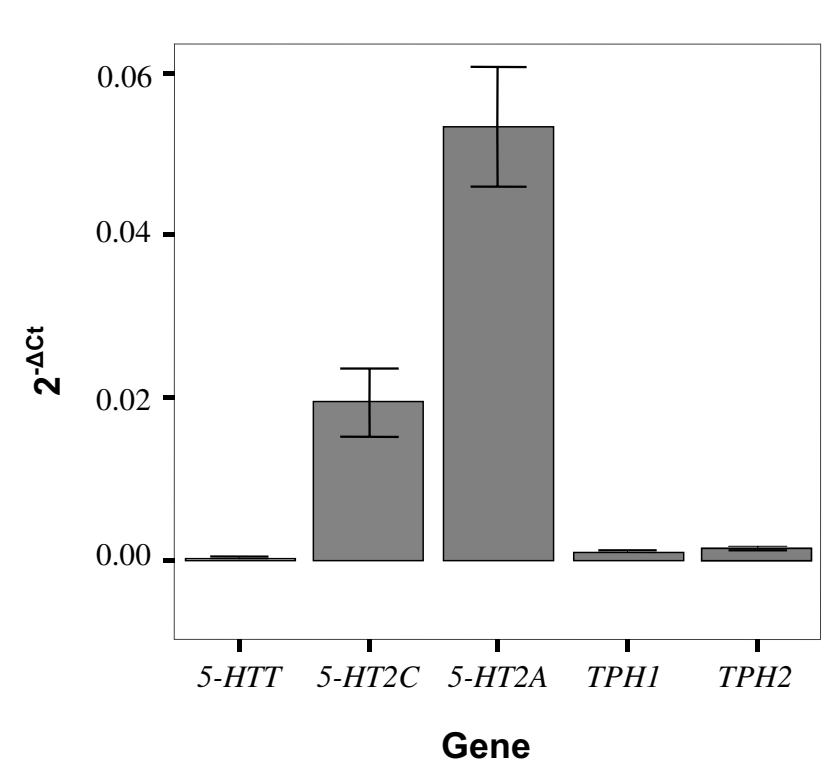

Figure I

Bar graph representing the expression (2- $\Delta \mathrm{Ct})$ of five serotonergic genes before controlling for brain region, genotype or gender. All genes are expressed in the brain, 5-HTT showing the lowest expression and 5-HT2A the highest. Bars represent mean and error bars represent standard error of the mean (s.e.m).

included 5-HT2C $(\mathrm{F}=19.297, \mathrm{p}<0.001), 5-H T 2 A(\mathrm{~F}=$ 17.952, $\mathrm{p}<0.001)$ and TPH2 $(\mathrm{F}=4.294, \mathrm{p}=0.001)$, and are represented in the bar charts of Figure 3, 4 and 5, respectively. The significant differences were consistently described by lower expression in the cerebellum compared to other brain regions as shown in Table 1.

\section{Effect of genotype on gene expression}

Genotype frequencies and results of ANOVA of the effects of genotype on gene expression are shown in Table 2. As 5-HT2C is localised to the X-chromosome, we split the sample by gender when assessing genotype effects. TPH1 did not show any variation in genotype (all samples were "GG" after successful digestion, $\mathrm{N}=11$ ), and so no further analyses could be performed for this gene. In general, there were no significant effects of genotype on overall brain expression of any of the genes that were analysed. There appears to be a dose-dependant effect on expression of the 5-HT2A gene by A-1438G genotype (mean $2^{-\Delta \mathrm{Ct}} \pm$ S.D.; AA genotype $=0.041 \pm 0.048$, AG genotype $=0.048$ \pm 0.052 , GG genotype $=0.054 \pm 0.065 ;$ ANOVA $\mathrm{F}=0.02$, $\mathrm{p}=0.983$ ). However, this failed to reach significance. Due to the small numbers in the groups stratified by genotype and allele frequency, further analysis of the effects of polymorphisms on within-brain region expression could not be reliably performed. 


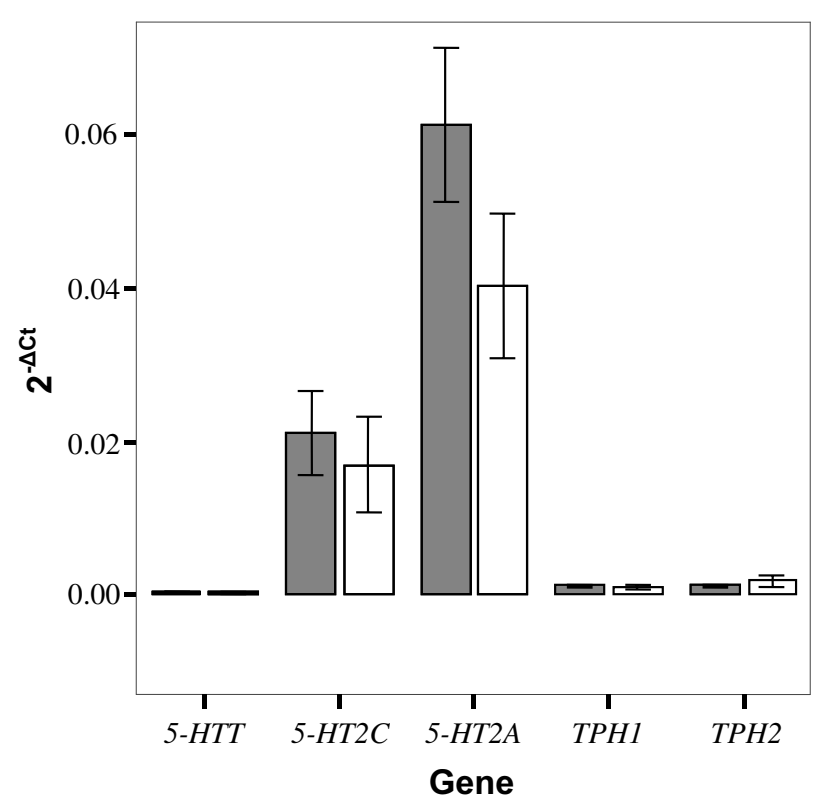

Figure 2

Bar graph representing the effect of gender on expression (2- $-\Delta \mathrm{Ct})$ of the five genes in all brain regions. Males (grey bars) and females (white bars) represent the mean and error bars representing s.e.m. No significant differences in expression are observed.

\section{TPHI vs. TPH2 expression}

Overall expression of TPH1 is not significantly different to that of TPH2 in this sample $(\mathrm{t}=1.613, \mathrm{p}=0.101$, mean 2 $\Delta \mathrm{Ct} \pm$ S.D.; TPH1 $=0.001 \pm 0.0008, \mathrm{~N}=68 ;$ TPH $2=0.001$ $\pm 0.002, N=63)$. However, when the data were further analysed for each brain region the expression of TPH1 was significantly higher than TPH2 in the striatum $(\mathrm{t}=2.487$, $\mathrm{p}=0.022$ ) and cerebellum $(\mathrm{t}=4.297, \mathrm{p}<0.001)$ (See Figure 6). There appear to be differences in the expression of TPH1 and TPH2 in the hippocampus and thalamus but as only a small number of data points were obtained for these brain regions, no significant differences could be determined. In addition, no significant differences exist between the relative expression of TPH1 and TPH 2 when stratified by gender (data not shown).

As the possible presence of Alzheimer's disease at death was recorded for 8 individuals, we tested for its possible impact on transcription. However, there was no significant influence of this phenotype on the difference in gene expression levels in all brain regions tested $($ TPH $1, \mathrm{t}=$ 1.33, d.f. $=13, \mathrm{p}=0.21, \mathrm{TPH} 2, \mathrm{t}=0.62$, d.f. $=13, \mathrm{p}=0.55$; $5-H T 2 A, \mathrm{t}=2.17$, d.f. $=8, \mathrm{p}=0.06 ; 5-H T 2 C, \mathrm{t}=0.85$, d.f. $=13, \mathrm{p}=0.41 ; 5-H T T, \mathrm{t}=2.04$, d.f. $=13, \mathrm{p}=0.06)$.

\section{Discussion}

This is the first investigation, to our knowledge, that compares the expression patterns of different serotonergic

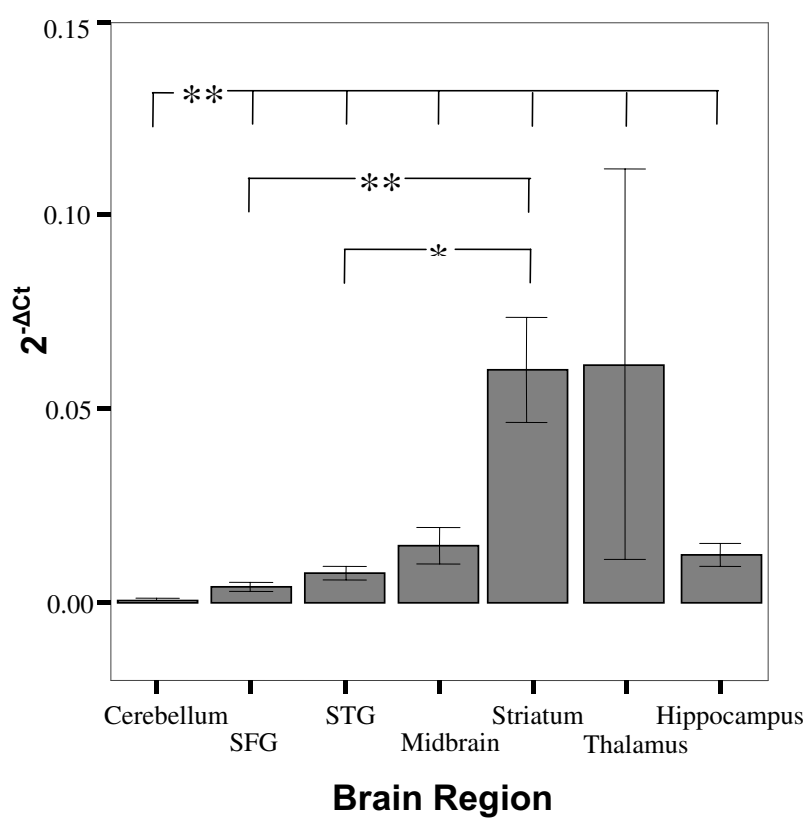

Figure 3

Bar graph describing the expression (2- $-\Delta \mathrm{Ct})$ of 5-HT2C in various brain regions. There are significant differences in expression (denoted by $* *$ [ $<<0.00 \mathrm{I}]$ ) across the brain regions, mainly due to lower expression of genes in the cerebellum. The symbol * represents a significant difference $\mathrm{P}=$ 0.003 between $5-H T 2 C$ expression in striatum and STG brain regions (see Table I). Bars represent the mean and error bars represent s.e.m. The groups representing expression in the thalamus have $\mathrm{N}=2$.

genes in various human post-mortem brain regions. The results suggest that all five serotonergic genes are expressed in human post-mortem brain tissue and significant overall differences in expression of 5-HT2A, 5-HT2C and $\mathrm{TPH} 2$ were observed between the various brain regions analysed. This is in agreement with previous findings that show variation in receptor densities between brain regions [28-30], and suggests that these differences in protein levels might be determined by transcriptional regulation to some degree. Differences in abundance of these various serotonergic transcripts throughout the brain suggest differential gene regulation between specific brain regions. Therefore, it is important to take into consideration the brain region from which the mRNA is derived when performing comparative post-mortem brain expression studies.

Perhaps most surprisingly, there appeared to be little effect of genetic variation on the overall brain expression of the genes we analysed. Although it has been suggested that expression of all five genes is regulated by promoter polymorphisms in vitro $[11,12,20,22,31]$, we did not observe the same effect ex vivo. Similar results have been 


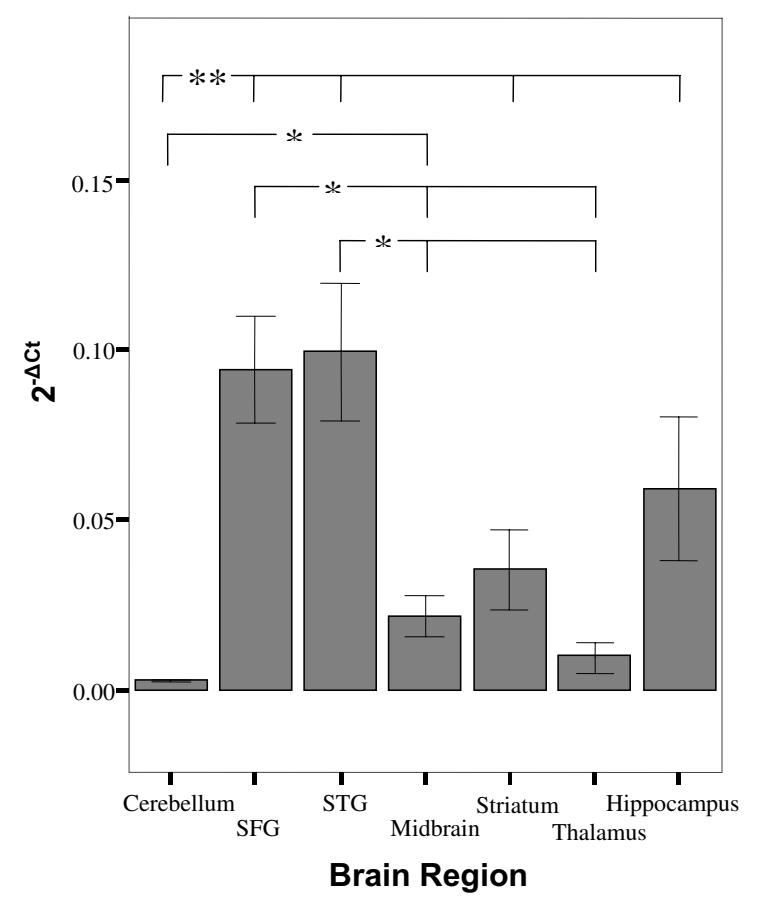

Figure 4

Bar graph describing the expression (2- $\Delta \mathrm{Ct})$ of $5-H T 2 A$ in various brain regions. There are significant differences in expression (denoted by $* *$ [ $<0.00 \mathrm{I}]$ and $*$ [p $\leq 0.04]$ ) across the brain regions, mainly due to lower expression of genes in the cerebellum (see Table I). Bars represent the mean and error bars represent s.e.m.

observed in previous expression studies in human postmortem brain. For example, differences in 5-HT2A expression were not observed between the ' $\mathrm{A}$ ' and ' $\mathrm{G}$ ' allele of the 5-HT2A A-1438G SNP [21], and allelic ratios of 5-HTT mRNA are not correlated to 5-HTTLPR genotype in human pons [32] or brainstem [33]. Whilst our data are in agreement with these findings, interpretation should be with some caution due the small sample size for each genotype group. This limits our ability to determine any brain region-specific effects of genetic variation on gene expression. Therefore these findings will need to be confirmed by using a larger sample-size in future studies. In addition, other potential confounders that were not measured could have an effect. For example, there has been a report of 5-HT2A imprinting in human fibroblasts and brain [34], although other independent studies found no further evidence for this phenomenon [21,35]. Overall, the data described here suggest that the postulated functional polymorphisms do not affect gene expression and this may reflect the complexity of gene regulation ex vivo.

No effects of gender on expression levels were observed for any of the genes within this sample. Interestingly, little

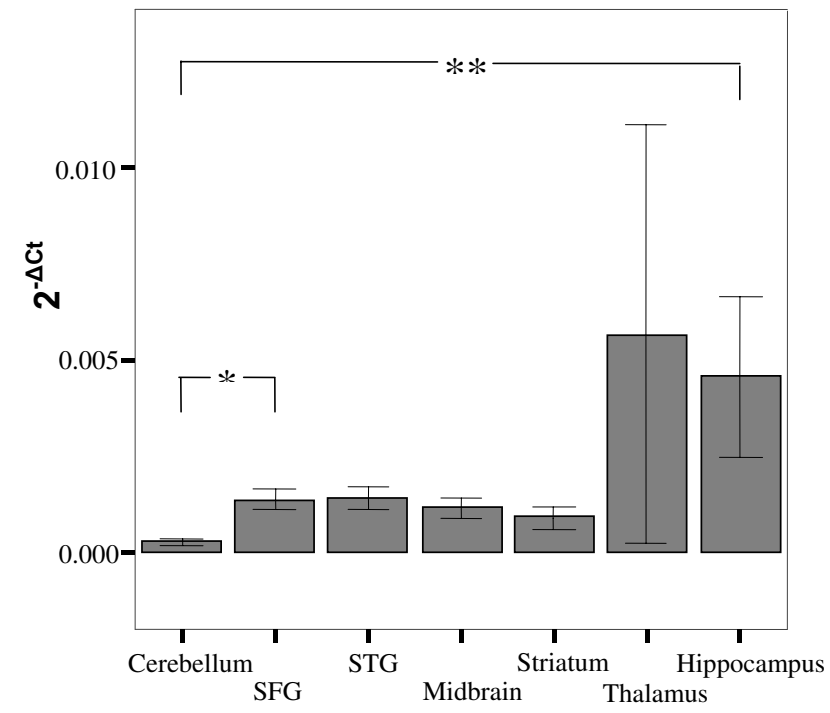

Brain Region

\section{Figure 5}

Bar graph describing the expression (2- $\Delta \mathrm{Ct})$ of TPH2 in various brain regions. There are significant differences in expression (denoted by $* *[\mathrm{p}=0.00 \mathrm{I}]$ and $*[\mathrm{p}=0.0 \mathrm{II}]$ ) across the brain regions, mainly due to lower expression of genes in the cerebellum (see Table I). Bars represent the mean and error bars represent s.e.m. The groups representing expression in the thalamus have $\mathrm{N}=2$.

data exist to date regarding the effect of gender on the expression of human serotonergic genes. However, there is evidence to suggest that gender-specific hormones might exert some regulatory effect on expression in rodents and primates. In Rhesus macaques, administration of oestrogen and progesterone resulted in a decrease in expression of 5-HT2C in the hypothalamus [36], whilst treatment of rats with oestradiol lead to a decrease in 5HT2C expression in the hippocampus [37]. Subsequently, the expression of both TPH1 and TPH 2 was shown to increase in the dorsal raphe nuclei of both mice [38] and macaques [39] following oestradiol administration. In addition, both testosterone and oestrogen were capable of increasing the number of 5-HTT cells in castrated male rats [40]. A limitation of the observations of our studies regarding the situation in humans is that the tissue donors were elderly, and reports of the normal levels of sex hormones within this age group are conflicting $[41,42]$.

Finally, the results observed here reveal that TPH1 expression is detected in all investigated brain regions at a comparable or higher level than that of TPH2. These data confirm recent findings [10], where TPH1 expression was observed in human brain, and that expression of TPH1 was significantly higher than that of TPH2 in some of the 
Table I: Results of comparisons of gene expression levels for those genes showing differences between brain regions

\begin{tabular}{|c|c|c|c|c|c|c|c|}
\hline \multirow{2}{*}{$\begin{array}{l}\text { Gene } \\
\text { 5-HT2C }\end{array}$} & \multirow{2}{*}{$\begin{array}{l}\text { Brain region I } \\
\text { CEREBELLUM }\end{array}$} & \multirow{2}{*}{$\begin{array}{l}\text { Brain region } 2 \\
\text { SFG }\end{array}$} & \multirow{2}{*}{$\begin{array}{l}\text { Mean Difference } \\
(I-2) \\
-0.779\end{array}$} & \multirow{2}{*}{$\begin{array}{l}\text { Std. Error } \\
0.176\end{array}$} & \multirow{2}{*}{$\begin{array}{l}\text { Bonferroni-corrected } \\
p \text { value }\end{array}$} & \multicolumn{2}{|c|}{ 95\% Confidence Intervals } \\
\hline & & & & & & -1.334 & -0.223 \\
\hline & & STG & $-1.04 \mid$ & 0.179 & $<0.001$ & -1.606 & -0.476 \\
\hline & & STRIATUM & -1.748 & 0.173 & $<0.001$ & -2.295 & -1.201 \\
\hline & & MIDBRAIN & -1.180 & 0.210 & $<0.001$ & -1.843 & -0.518 \\
\hline & & THALAMUS & -1.835 & 0.358 & $<0.001$ & -2.965 & -0.705 \\
\hline & & HIPPOCAMPUS & -1.338 & 0.247 & $<0.001$ & -2.117 & -0.559 \\
\hline & STRIATUM & SFG & 0.969 & 0.170 & $<0.001$ & 0.432 & 1.506 \\
\hline & & STG & 0.706 & 0.173 & 0.003 & 0.159 & 1.253 \\
\hline \multirow[t]{9}{*}{$5-H T 2 A$} & CEREBELLUM & SFG & -1.430 & 0.164 & $<0.001$ & -1.948 & -0.911 \\
\hline & & STG & -1.427 & 0.164 & $<0.001$ & -1.946 & -0.909 \\
\hline & & MIDBRAIN & -0.706 & 0.196 & 0.012 & -1.324 & -0.088 \\
\hline & & STRIATUM & -0.934 & 0.170 & $<0.001$ & $-1.47 \mid$ & -0.397 \\
\hline & & HIPPOCAMPUS & -1.267 & 0.230 & $<0.001$ & -1.994 & -0.541 \\
\hline & SFG & MIDBRAIN & 0.724 & 0.193 & 0.008 & 0.113 & 1.335 \\
\hline & & THALAMUS & 0.905 & 0.279 & 0.039 & 0.023 & 1.788 \\
\hline & STG & MIDBRAIN & 0.721 & 0.193 & 0.008 & 0.111 & 1.332 \\
\hline & & THALAMUS & 0.903 & 0.279 & 0.040 & 0.021 & 1.785 \\
\hline \multirow[t]{2}{*}{ TPH2 } & CEREBELLUM & SFG & -0.746 & 0.203 & 0.011 & -1.392 & -0.101 \\
\hline & & HIPPOCAMPUS & -1.205 & 0.277 & 0.001 & -2.087 & -0.323 \\
\hline
\end{tabular}

Mean differences were calculated where relative expression values of brain region 2 were subtracted from the value of brain region I. The significance levels and $95 \%$ confidence levels are listed for comparisons that show significant differences only.

brain regions we also examined (frontal cortex, thalamus, hippocampus, hypothalamus and amygdala). Our data show that TPH1 expression is higher than that of TPH2 in the striatum and cerebellum, but not the hippocampus. This inconsistency could be related to variables we could not measure, or factors such as the differing mean ages of samples analysed in this study and that by Zill and colleagues [10], since there is evidence that increasing age enlarges the heterogeneity of gene expression contributing to greater inter-individual variability in expression [43]. Additionally, the discrepancy in our results with that of Zill and colleagues could be due to the existence of transcriptional variants for TPH2 mRNA in humans. Recent evidence in rats has revealed that TPH2 has two transcriptional variants one of which is expressed at a very low level [44]. The potential of TPH2 mRNA splice variants has not been demonstrated in humans to date and warrants future investigation.

The original discovery of the novel TPH2 isoform led to the hypothesis that it was TPH2 not TPH1 that was the relevant 5-HT catabolic gene in brain tissue based on its much higher expression level (150 times more) in the brain stem of mice [9]. This region contains raphe nuclei which are rich in serotonergic neurons and our results differ from these previous studies as we focused on several other brain areas which did not include the brain stem. Prior to discovery of $\mathrm{TPH} 2$, brain regional differences in TPH densities were traditionally explained by differences in translational efficiencies of splice variants [45]. However, this might now be explained by region specific expression of the two TPH isoforms. Our data support this hypothesis as TPH1 is expressed in all brain regions, and that there are brain region specific differences in expression of TPH1 and TPH2. Although emerging data suggest that TPH1 is not sufficient to drive serotonergic metabolism in the brain, it is expressed, albeit at differing levels, and as such does not preclude its role in the regulation of serotonergic functioning. Furthermore, TPH1 in the pineal gland is essential in the synthesis of melatonin, a mechanism by which it can, in turn, influence serotonergic functioning and behaviour [46].

Although we attempted to control for factors that could have an effect on results described here, there are other confounding issues to consider. Firstly, the sample size is small, which might lead to bias in group comparisons. Furthermore, specific conditions at the time of death and post-mortem (e.g. Post mortem interval, PMI) significantly affect RNA integrity and abundance [47-50]. However, these studies show that post-mortem intervals of 48 hours do not affect expression levels. The PMI of the postmortem samples utilised in this study were $38.67 \pm 16.62$ hours (mean \pm S.D.) and within the limit so that gene expression levels would not be affected.

Real-time qPCR ('TaqMan') was utilised to quantify gene expression since it is a highly reproducible and sensitive technique $[51,52]$. The relative quantification method of analysis was employed which compares the expression level of a target gene to the expression of an endogenous control gene. This high-throughput method has been suc- 
Table 2: Results of expression analyses by genotype

\begin{tabular}{|c|c|c|c|c|c|c|c|c|c|}
\hline \multirow[b]{2}{*}{ Gene/Marker } & & \multirow[b]{2}{*}{ Genotype } & \multirow[b]{2}{*}{$\begin{array}{l}\text { Genotype } \\
\text { Frequency } \\
(\mathrm{N})\end{array}$} & \multirow[b]{2}{*}{ Allele } & \multirow[b]{2}{*}{$\begin{array}{l}\text { Allele } \\
\text { Frequency } \\
(\mathbf{N})\end{array}$} & \multicolumn{2}{|c|}{ H-W test } & \multicolumn{2}{|c|}{ ANOVA } \\
\hline & & & & & & $\chi^{2}$ value & $P$ & $\boldsymbol{F}$ & $P$ \\
\hline $5-H T 2 A$ & & AA & $0.29(4)$ & $A$ & $0.46(13)$ & 0.57 & 0.75 & 0.02 & 0.983 \\
\hline \multirow[t]{3}{*}{ A- $1438 G$} & & AG & $0.36(5)$ & G & $0.54(15)$ & & & & \\
\hline & & GG & $0.36(5)$ & & & & & & \\
\hline & & $N=14$ & & & & & & & \\
\hline \multicolumn{10}{|l|}{$5-H T 2 C$} \\
\hline \multirow[t]{7}{*}{ promoter microsatellite } & $M$ & Z & $0.67(4)$ & & & & & 0.02 & 0.98 \\
\hline & & Z-6 & $0.33(2)$ & & & & & & \\
\hline & $\mathrm{F}$ & Z-6/Z-6 & $0.14(1)$ & Z-6 & $0.36(5)$ & 0.84 & 0.89 & 0.14 & 0.933 \\
\hline & & Z-6/Z & $0.29(2)$ & Z & $0.57(8)$ & & & & \\
\hline & & $Z-6 / Z+2$ & $0.14(1)$ & $Z+2$ & $0.07(\mathrm{I})$ & & & & \\
\hline & & $\mathrm{Z} / \mathrm{Z}$ & $0.43(3)$ & & & & & & \\
\hline & & $N=13$ & & & & & & & \\
\hline TPH2 & & GG & $0.69(9)$ & G & $0.85(22)$ & 0.94 & 0.33 & 1.47 & 0.23 \\
\hline \multirow[t]{2}{*}{ G-703T } & & GT & $0.31(4)$ & $\mathrm{T}$ & $0.15(4)$ & & & & \\
\hline & & $N=13$ & & & & & & & \\
\hline 5-HTT & & SS & $0.07(I)$ & $S$ & $0.39(\mathrm{II})$ & 0.43 & 0.81 & 0.10 & 0.91 \\
\hline \multirow[t]{3}{*}{ 5-HTTLPR } & & SL & $0.64(9)$ & L & $0.61(17)$ & & & & \\
\hline & & LL & $0.29(4)$ & & & & & & \\
\hline & & $N=14$ & & & & & & & \\
\hline 5-HTT & & $10 / 10$ & $0.09(1)$ & 10 & $0.23(5)$ & 0.72 & 0.70 & 0.02 & 0.98 \\
\hline \multirow[t]{3}{*}{ Intron 2 VNTR } & & $10 / 12$ & $0.27(3)$ & 12 & 0.77 (I7) & & & & \\
\hline & & $12 / 12$ & $0.64(7)$ & & & & & & \\
\hline & & $N=11$ & & & & & & & \\
\hline
\end{tabular}

Genotype frequencies, allele frequencies, results of $\mathrm{H}-\mathrm{W}$ (Hardy-Weinberg) tests and ANOVA comparisons of gene expression levels $\left(\mathrm{log}_{(10)} 2^{2-\Delta C \mathrm{Ct}}\right)$ values for the polymorphic variants are shown. Genotypes of the $5-H T 2 C$ marker are split by gender (Males $=$ M; Females $=F$ ) since the males are hemizygotic.

cessfully used in previous gene expression studies with post-mortem human brain and biopsies [53,54]. However, there are some caveats to be made regarding choice of suitable endogenous control gene, especially in regards to expression stability. In this study, SDHA, UBC and $G A P D H$ housekeeping genes were used as endogenous controls based on previous data which showed these genes to be most stably expressed in human neuroblastoma cells [55]. The results did not reveal any significant differences between relative expression values when normalised to each of the endogenous control genes separately (data not shown), thus differential expression of control gene is unlikely to be a confounding factor.

\section{Conclusion}

This investigation has demonstrated the differential expression of 5-HT genes in several human post-mortem brain tissue regions using real-time qPCR. These data provide additional information that will be relevant for appropriate sample selection when performing gene expression studies involving human brain. Both gender and transcriptionally-relevant polymorphisms appear to have little influence on ex vivo expression within this sample suggesting that complex interactions present in human brain tissue might eclipse the genetic effects that are consistently observed in vitro. These results, taken together with those from alternative approaches such as animal models, in vitro and neuroimaging studies, will contribute to the understanding of these interactions and inform researchers of the mechanisms that regulate serotonergic gene expression in human brain.

\section{Methods}

The sample consisted of brain tissue collected from 15 individuals post-mortem ( 9 Male, 6 female) provided by the Maudsley Brain Bank (Department of Neuropathology, Institute of Psychiatry, London, UK) and stored at $70^{\circ} \mathrm{C}$ prior to use. These individuals were normal $(\mathrm{N}=7)$ adults and Alzheimer's patients $(\mathrm{N}=8)$ with agonal states of either cardiac failure, bronchopneumonia, myocardial infarction, hypertension, coronary occlusion, carcinoma of left kidney, ischaemic heart disease, pulmonary embolus. Mean age at death for the sample was $78.0 \pm 7.4$ years (mean \pm s.d.), and mean post-mortem delay was $38.7 \pm$ 16.6 (mean \pm s.d.) hours. No significant differences were observed between males and females with regard to either age at death (males: $77.6 \pm 7.0$ years (mean \pm s.d.); females: $79.2 \pm 8.6$ years (mean \pm s.d.) $\mathrm{t}=-0.381, \mathrm{p}=$ 0.712 ) or post-mortem delay (males $38.2 \pm 14.1 \mathrm{hrs}$ (mean \pm s.d. $)$; females $39.3 \pm 21.3$ hrs (mean \pm s.d. $) ; t=-$ 


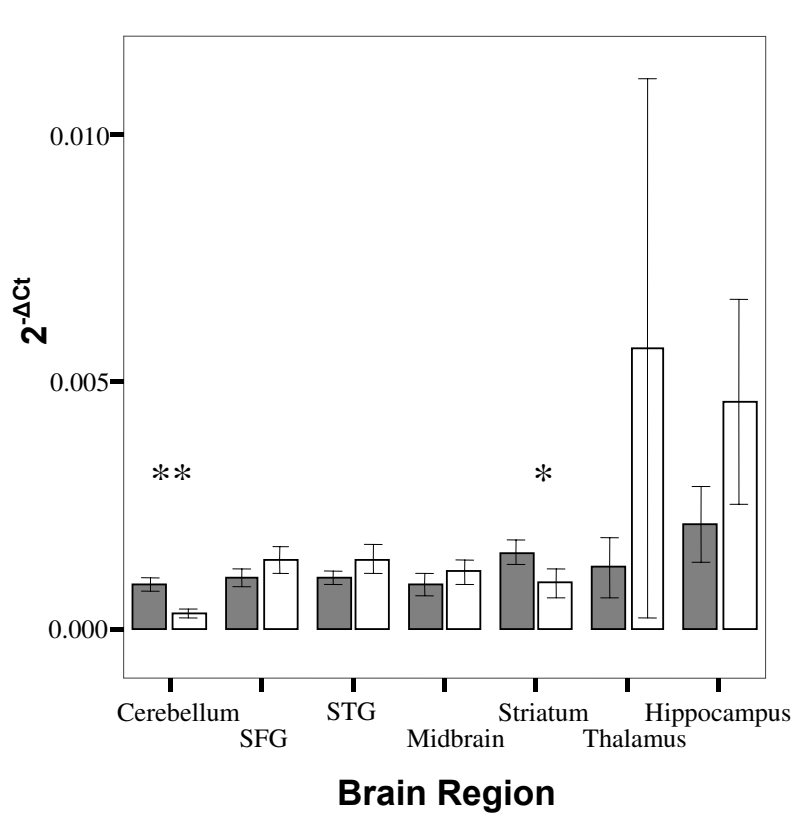

Figure 6

Bar graph of mean expression (2- $\Delta \mathrm{Ct})$ of TPHI (grey bars) versus TPH2 (white bars) and error bars representing s.e.m. Both genes are expressed in all brain regions, and TPHI expression is significantly higher than TPH2 in both the striatum $(t=2.487, p=0.022$, denoted by $*)$ and cerebel$\operatorname{lum}(t=4.297, p<0.001$, denoted by $* *)$. The groups representing TPH2 expression in the hippocampus and thalamus have a much larger variance than that of TPHI, probably due to the smaller number of individuals in these groups (hippocampus $\mathrm{N}=5$, thalamus $\mathrm{N}=2$ ).

$0.112, \mathrm{p}=0.913)$. From each individual, samples from up to 7 different brain regions were collected and included the following: superior frontal gyrus (SFG; $N=15)$, superior temporal gyrus (STG; $N=15)$, hippocampus $(\mathrm{N}=7)$, cerebellum $(\mathrm{N}=15)$, midbrain $(\mathrm{N}=9)$, thalamus $(\mathrm{N}=3)$ and striatum $(\mathrm{N}=14)$. The Ethical Committee (Research) at the Institute of Psychiatry considered and approved this experimental project and the reference study number is $167 / 00$.

\section{Nucleic acid preparation}

Brain tissue was stored at $-80^{\circ} \mathrm{C}$ prior to total RNA and DNA extraction using TRI reagent (Sigma, UK) following the manufacturer's instructions. Total RNA was DNase I treated using Qiagen RNeasy kit (Qiagen, UK) and DNase I (Qiagen, UK) following manufacturer's recommendations. cDNA was generated from total RNA using the TaqMan RT-PCR kit (Applied Biosystems, UK). Briefly, $1 \mu \mathrm{g}$ of total RNA was reverse transcribed with $5.5 \mathrm{mM}$ of $\mathrm{MgCl}$, $500 \mu \mathrm{M}$ of each dNTP, $2.5 \mu \mathrm{M}$ random hexamers and 0.4 $\mathrm{U} / \mu \mathrm{L}$ RNase inhibitor in a total volume of $20 \mu \mathrm{l}$. Samples were incubated at $25^{\circ} \mathrm{C}$ for 10 minutes, followed by $48^{\circ} \mathrm{C}$ for 30 minutes and then denatured at $95^{\circ} \mathrm{C}$ for 5 minutes in a thermocycler.

Relative quantitative real-time PCR using 'TaqMan' Primers and probes for each gene were obtained via 'Assays-on-demand' (Applied Biosystems, UK). All probes were tested for equal reaction efficiencies prior to use by making a serial dilution of a single cDNA sample (range $1-10^{3}$ dilution). All probes showed an amplification efficiencies in the accepted range $(0.98-1.02)$. Assay ID numbers are listed in Table 3 . All probes are designed to span adjacent exons to minimise effects of any residual DNA contamination.

TaqMan reactions were performed using $0.5 \mu$ l Assays-ondemand primer/probe, $5 \mu \mathrm{l} 2 \times$ TaqMan mastermix (Applied Biosystems, UK), $0.5 \mu \mathrm{l}$ cDNA and appropriate volume of primer and probe in a total volume of $10 \mu \mathrm{l}$. Concurrently, three housekeeping endogenous controls were assayed for each individual sample for normalisation purposes (Succinate Deydrogenase (SDHA), Ubiquitin $\mathrm{C}$ (UBC) and Glyceraldehyde-3-phosphate dehydrogenase (GAPDH) [55]). Each experiment was performed in triplicate. The TaqMan reaction was carried out using an ABI7900HT sequence detection system set up in absolute quantification mode. Cycling conditions were one cycle of $95^{\circ} \mathrm{C}$ at 10 minutes, followed by 40 cycles of $95^{\circ} \mathrm{C}$ at $15 \mathrm{sec}$ and $60^{\circ} \mathrm{C}$ for $1 \mathrm{~min}$. On completion of PCR, Ct values were generated using SDS 2.1. software.

\section{Genotyping}

The following polymorphisms were genotyped: 5HTTLPR and intron 2 VNTR (5-HTT), T-346G (TPH1), G703T (TPH2), A-1438G (5-HT2A), GTn microsatellite (5$H T 2 C)$. Details of these markers, PCR reaction conditions and detection methods are given in Table 3. PCR reactions consisted of $2.5 \mu \mathrm{l} \times 10$ PCR reaction buffer IV (Abgene, UK), $200 \mathrm{mM}$ dNTPS (Abgene, UK), 1 unit Taq polymerase (Promega, UK), $10 \mathrm{pmol}$ each primer, appropriate concentration of $\mathrm{MgCl}_{2}$ and $25 \mathrm{ng}$ template DNA up to 25 $\mu \mathrm{l}$. Cycling conditions consisted of initial denaturation at $94^{\circ} \mathrm{C}$ for 4 minutes followed by 30 cycles of $95^{\circ} \mathrm{C}$ for 1 minute, appropriate annealing temperature for 1 minute and $72^{\circ} \mathrm{C}$ for 1 minute, followed by a final elongation step at $72^{\circ} \mathrm{C}$ for 4 minutes. PCR reactions were carried out using an $\mathrm{MJ}$ research tetrad thermal cycler (MJ research, UK).

Enzyme digests were carried out using MspI (Promega, UK) or MslI (NEB, USA) following manufacturer's instructions. Digested samples were subjected to agarose gel electrophoresis using a 2\% agarose gel (Abgene, UK) and visualised using UV transillumination (UVP, UK). Those assays requiring capillary gel electrophoresis were analysed using an ABI3100 (Applied Biosystems) set up in 
Table 3: Details of qPCR and genotyping assay primers and conditions

\begin{tabular}{|c|c|c|c|c|c|c|c|}
\hline Gene & $\begin{array}{l}\text { Assay on } \\
\text { demand ID }\end{array}$ & $\begin{array}{l}\text { Genotype } \\
\text { variant }\end{array}$ & $\begin{array}{c}\text { Genotype } \\
\text { detection method }\end{array}$ & $\begin{array}{l}\text { Genotyping primers (forward and } \\
\text { reverse) }\end{array}$ & Size (bp) & $\begin{array}{l}\text { Temp } \\
{ }^{\circ} \mathrm{C}\end{array}$ & $\begin{array}{l}\mathrm{MgCl}_{2} \\
(\mathrm{mM})\end{array}$ \\
\hline TPHI & Hs00I88220_m I & T-346G & $\begin{array}{l}\text { Msll enzyme } \\
\text { digest }\end{array}$ & $\begin{array}{l}\text { 5'CTTCGTTATGTGTACAGTCC-3' } \\
\text { 5'TAGGACTGCAGTGCTTCTC-3' }\end{array}$ & $\begin{array}{l}\mathrm{G}=365 \\
\mathrm{~T}=305+60\end{array}$ & 59 & 2 \\
\hline \multirow[t]{2}{*}{ TPH2 } & Hs00542783_m I & G-703T & $\begin{array}{l}\text { Taqman allelic } \\
\text { discrimination }\end{array}$ & $\begin{array}{l}\text { 5'ACACTCACACATTTGCATGCAC-3' } \\
\text { 5'CATTGACCAACTCCATTTTATGTTAATA } \\
\text { AGCT-3' }\end{array}$ & & & \\
\hline & & & & $\begin{array}{l}\text { TPH2 taqman genotyping probe sequences: } \\
\text { VIC-CTTGACATATTCTAATTT } \\
\text { FAM-ACTTGACATATTATAATTTT }\end{array}$ & & & \\
\hline 5-HT2A & Hs00I6724I_ml & A-1438G & Mspl enzyme digest & $\begin{array}{l}\text { 5'AAGCTGCAAGGTAGCAACAGC-3' } \\
\text { 5'AACCAACTTATTTCCTACCAC-3' }\end{array}$ & $\begin{array}{l}A=468 \\
G=244+224\end{array}$ & 56 & 1.5 \\
\hline 5-HT2C & Hs00I68365_ml & $\begin{array}{l}\text { GTn promoter } \\
\text { microsatellite } \\
-1027 \mathrm{bp}\end{array}$ & capillary electrophoresis & $\begin{array}{l}\text { FAM5'GGGAGTTTCAAAGCTTGATGA3' } \\
\text { 5'GTTTCTTAGACCCATGGTGGAGATGG-3' }\end{array}$ & $\begin{array}{l}\text { 259; } \\
\text { Z-6 allele }\end{array}$ & 59.5 & 2.5 \\
\hline \multirow[t]{2}{*}{ 5-HTT } & Hs00I690I0_ml & 5-HTTLPR & $\begin{array}{l}\text { agarose gel } \\
\text { electrophoresis }\end{array}$ & $\begin{array}{l}\text { 5'ATGCCAGCACCTAACCCCTAATGT-3' } \\
\text { 5'GGACCGCAAGGTGGGCGGGA-3' }\end{array}$ & $\begin{array}{l}419 \\
16 \text { rpt 'L' }\end{array}$ & 66 & 1.5 \\
\hline & & intron2 VNTR & $\begin{array}{l}\text { agarose gel } \\
\text { electrophoresis }\end{array}$ & $\begin{array}{l}\text { 5'GTCAGTATCACAGGCTGCGAG-3' } \\
\text { 5'TGTTCCTAGTCTTACGCCAGT-3' }\end{array}$ & STin I $2 \sim 299$ & 54 & 1.5 \\
\hline GAPDH & Hs00266705_gl & $\mathrm{n} / \mathrm{a}$ & & & & & \\
\hline UBC & Hs00824723_ml & $\mathrm{n} / \mathrm{a}$ & & & & & \\
\hline SDHA & $\mathrm{Hs} 00188166 \_\mathrm{ml}$ & $\mathrm{n} / \mathrm{a}$ & & & & & \\
\hline
\end{tabular}

Assay-on-demand' IDs correspond to product order numbers (Applied Biosystems).

genotyping mode. $1 \mu \mathrm{l}$ PCR product was prepared in $12 \mu \mathrm{l}$ HI-DI formamide and $0.4 \mu \mathrm{l}$ GSRox size standard (Applied Biosystems, UK), denatured at $95^{\circ} \mathrm{C}$ for 10 minutes and snap cooled on ice. Data were analysed using Genotyper V3.6 software (Applied Biosystems, UK).

\section{Statistical analyses}

Mean triplicate Ct values for each sample were calculated, and outliers within the triplicates removed using Grubb's method. Briefly, if the obtained $\mathrm{Z}$ value (the difference between the investigated $\mathrm{Ct}$ and the mean $\mathrm{Ct}$ divided by the $\mathrm{SD}$ ) exceeded the critical value 1.15, the sample was considered an outlier and removed from further analysis. The mean $\mathrm{Ct}$ values were used to calculate relative expression using the $\Delta \mathrm{Ct}$ method [56] where normalisation using multiple reference genes was employed. The normalisation index was calculated as the arithmetic mean $\mathrm{Ct}$ of the three housekeeping genes $(G A P D H, U B C, S D H A)$. The $\Delta \mathrm{Ct}$ was then calculated by subtracting the normalisation index from the mean target $\mathrm{Ct}$, and then the relative expression is calculated using the formula $2^{-\Delta \mathrm{Ct}}$. Relative expression values $\left(2^{-\Delta \mathrm{C} t}\right)$ were log-transformed prior to analysis since these values are not normally distributed [57]. Student's $t$ test or ANOVA with post-hoc Bonferroni correction and Games-Howell test were performed.

The statistical package for social scientists (SPSS, USA) was employed in all analyses, and grouping variables were gender, genotype and brain region.

\section{Authors' contributions}

KS participated in design of the study, carried out sample preparation, qPCR, statistical analyses and drafted the manuscript. AT participated in statistical analyses. NK per- formed sample collection. IWC participated in design of the study. UMD conceived of the study, participated in its design and coordination, was involved in statistical analyses and helped draft the manuscript. All authors read and approved the final manuscript.

\section{Acknowledgements}

The research study was supported by the Medical Research Council (MRC) with an MRC Component Grant (\#G0000 197). We thank Dr. Michael Parsons for his kind help with the 5-HT2A genotyping. We also acknowledge Clare Wright and Mark Frost for technical assistance with sample preparation.

\section{References}

I. Lucki I: The spectrum of behaviors influenced by serotonin. Biological Psychiatry 1998, 44:15I-162.

2. Veenstra-VanderWeele J, Anderson GM, Cook EH Jr: Pharmacogenetics and the serotonin system: initial studies and future directions. Eur J Pharmacol 2000, 4I 0:165-181.

3. Cravchik A, Goldman D: Neurochemical individuality - Genetic diversity among human dopamine and serotonin receptors and transporters. Archives of General Psychiatry 2000, 57: $1105-1114$.

4. Arango V, Huang YY, Underwood MD, Mann J]: Genetics of the serotonergic system in suicidal behavior. Journal of Psychiatric Research 2003, 37:375-386.

5. Gingrich JA, Hen R: Dissecting the role of the serotonin system in neuropsychiatric disorders using knockout mice. Psychopharmacology 200I, I55: I-10.

6. D'Souza UM, Craig IW: Functional polymorphisms in dopamine and serotonin pathway genes. Human Mutation 2006, 27: I-I3.

7. Stoltenberg SF, Burmeister M: Recent progress in psychiatric genetics - some hope but no hype. Human Molecular Genetics 2000, 9:927-935.

8. Lesch KP, Bengel D, Heils A, Sabol SZ, Greenberg BD, Petri S, et al: Association of anxiety-related traits with a polymorphism in the serotonin transporter gene regulatory region. Science 1996, 274:1527-I53I.

9. Walther DJ, Bader M: A unique central tryptophan hydroxylase isoform. Biochemical Pharmacology 2003, 66:1673-1680.

10. Zill P, Buttner A, Eisenmenger W, Moller HJ, Ackenheil M, Bondy B: Analysis of tryptophan hydroxylase I and II mRNA expres- 
sion in the human brain: A post-mortem study. Journal of Psychiatric Research 2007, 41:168-173.

II. Sun HS, Fann CSJ, Lane HY, Chang YT, Chang CJ, Liu YL, et al.: A functional polymorphism in the promoter region of the tryptophan hydroxylase gene is associated with alcohol dependence in one aboriginal group in Taiwan. Alcoholism-Clinical and Experimental Research 2005, 29: I-7.

12. Chen GL, Vallender EJ, Miller GM: Functional characterization of the human $\mathrm{TPH} 25$ ' regulatory region: untranslated region and polymorphisms modulate gene expression in vitro. Human Genetics 2008, I 22:645-657.

13. Frazer A, Maayani S, Wolfe BB: Subtypes of Receptors for Serotonin. Annu Rev Pharmacol Toxicol 1990, 30:307-348.

14. Barnes NM, Sharp T: A review of central 5-HT receptors and their function. Neuropharmacology 1999, 38:1083-1/52.

15. Pompeiano M, Palacios JM, Mengod G: Distribution of the Serotonin 5-Ht2 Receptor Family Messenger-Rnas - Comparison Between 5- $\mathrm{Ht}(2 \mathrm{~A})$ and 5-Ht(2C) Receptors. Molecular Brain Research 1994, 23:163-178.

16. Abramowski D, Rigo M, Duc D, Hoyer D, Staufenbiel M: Localization of the 5-hydroxytryptamine2C receptor protein in human and rat brain using specific antisera. Neuropharmacology 1995, 34:1635-1645.

17. Kulikov AV, Naumenko VS, Voronova IP, Tikhonova MA, Popova NK: Quantitative RT-PCR assay of 5-HTIA and 5-HT2A serotonin receptor mRNAs using genomic DNA as an external standard. J Neurosci Methods 2005, I 41:97-101.

18. Biver F, Lotstra F, Monclus M, Wikler D, Damhaut P, Mendlewicz J, et al.: Sex difference in $5 \mathrm{HT}(2)$ receptor in the living human brain. Neuroscience Letters 1996, 204:25-28.

19. Spurlock G, Heils A, Holmans P, Williams J, D'Souza UM, Cardno A, et al.: A family based association study of TI02C polymorphism in 5HT2A and schizophrenia plus identification of new polymorphisms in the promoter. Molecular Psychiatry 1998, 3:42-49.

20. Parsons MJ, D'Souza UM, Arranz MJ, Kerwin RW, Makoff AJ: The I438A/G polymorphism in the 5-hydroxytryptamine type $2 \mathrm{~A}$ receptor gene affects promoter activity. Biol Psychiatry 2004, 56:406-410.

21. Bray NJ, Buckland PR, Hall H, Owen MJ, O'Donovan MC: The serotonin-2A receptor gene locus does not contain common polymorphism affecting mRNA levels in adult brain. Mol Psychiatry 2004, 9: 109-II4.

22. Yuan X, Yamada K, Ishiyama-Shigemoto S, Koyama W, Nonaka K: Identification of polymorphic loci in the promoter region of the serotonin 5-HT2C receptor gene and their association with obesity and type II diabetes. Diabetologia 2000, 43:373-376.

23. Ozsarac N, Santha E, Hoffman B]: Alternative non-coding exons support serotonin transporter mRNA expression in the brain and gut. J Neurochem 2002, 82:336-344.

24. Heils A, Teufel A, Petri S, Seemann M, Bengel D, Balling U, et al:: Functional promoter and polyadenylation site mapping of the human serotonin (5-HT) transporter gene. I Neural Transm Gen Sect 1995, 102:247-254.

25. Nakamura $M$, Ueno $S$, Sano A, Tanabe $H$ : The human serotonin transporter gene linked polymorphism (5-HTTLPR) shows ten novel allelic variants. Mol Psychiatry 2000, 5:32-38.

26. MacKenzie A, Quinn J: A serotonin transporter gene intron 2 polymorphic region, correlated with affective disorders, has allele-dependent differential enhancer-like properties in the mouse embryo. Proc Natl Acad Sci USA 1999, 96: I 525I-I 5255

27. Fiskerstrand CE, Lovejoy EA, Quinn JP: An intronic polymorphic domain often associated with susceptibility to affective disorders has allele dependent differential enhancer activity in embryonic stem cells. FEBS Lett 1999, 458:17I-174.

28. Heisler LK, Cowley MA, Tecott LH, Fan W, Low MJ, Smart JL, et al.: Activation of central melanocortin pathways by fenfluramine. Science 2002, 297:609-6II.

29. Forutan F, Estalji S, Beu M, Nikolaus S, Hamacher K, Coenen HH, et al.: Distribution of 5 HT2A receptors in the human brain: comparison of data in vivo and post mortem. Nuklearmedizin 2002, 4I:197-201.

30. Marazziti D, Rossi A, Giannaccini G, Zavaglia KM, Dell'Osso L, Lucacchini $A$, et al.: Distribution and characterization of $[3 \mathrm{H}]$ mesulergine binding in human brain postmortem. Eur Neuropsychopharmacol 1999, 10:21-26.
31. Lesch KP, Bengel D, Heils A, Sabol SZ, Greenberg BD, Petri S, et al.: Association of anxiety-related traits with a polymorphism in the serotonin transporter gene regulatory region. Science 1996, 274: I527-|53|.

32. Lim JE, Papp A, Pinsonneault J, Sadee W, Saffen D: Allelic expression of serotonin transporter (SERT) MRNA in human pons: lack of correlation with the polymorphism SERTLPR. Mol Psychiatry 2006, II:649-662.

33. Johnson AD, Zhang Y, Papp AC, Pinsonneault JK, Lim JE, Saffen D, et al.: Polymorphisms affecting gene transcription and mRNA processing in pharmacogenetic candidate genes: detection through allelic expression imbalance in human target tissues. Pharmacogenet Genomics 2008, 18:78I-79I.

34. Bunzel R, Blumcke I, Cichon S, Normann S, Schramm J, Propping P, et al.: Polymorphic imprinting of the serotonin-2A (5-HT2A) receptor gene in human adult brain. Brain Res Mol Brain Res 1998, 59:90-92

35. Polesskaya OO, Sokolov BP: Differential expression of the " $\mathrm{C}$ " and " $\mathrm{T}$ " alleles of the 5-HT2A receptor gene in the temporal cortex of normal individuals and schizophrenics. J Neurosci Res 2002, 67:812-822.

36. Gundlah C, Pecins-Thompson M, Schutzer WE, Bethea CL: Ovarian steroid effects on serotonin IA, 2A and 2C receptor mRNA in macaque hypothalamus. Brain Res Mol Brain Res 1999, 63:325-339.

37. Birzniece V, Johansson IM, Wang MD, Backstrom T, Olsson T: Ovarian hormone effects on 5-hydroxytryptamine(2A) and 5hydroxytryptamine $(2 \mathrm{C})$ receptor $\mathrm{mRNA}$ expression in the ventral hippocampus and frontal cortex of female rats. Neurosci Lett 2002, 319:157-161.

38. Gundlah C, Alves SE, Clark JA, Pai LY, Schaeffer JM, Rohrer SP: Estrogen receptor-beta regulates tryptophan hydroxylase-I expression in the murine midbrain raphe. Biol Psychiatry 2005, 57:938-942.

39. Sanchez RL, Reddy AP, Centeno ML, Henderson JA, Bethea CL: A second tryptophan hydroxylase isoform, TPH-2 mRNA, is increased by ovarian steroids in the raphe region of macaques. Brain Res Mol Brain Res 2005, 135: 194-203.

40. McQueen JK, Wilson H, Sumner BE, Fink G: Serotonin transporter (SERT) mRNA and binding site densities in male rat brain affected by sex steroids. Brain Res Mol Brain Res 1999, 63:24I-247.

41. Bjornerem A, Straume B, Midtby M, Fonnebo V, Sundsfjord J, Svartberg J, et al.: Endogenous sex hormones in relation to age, sex, lifestyle factors, and chronic diseases in a general population: the Tromso Study. J Clin Endocrinol Metab 2004, 89:6039-6047.

42. Leifke E, Gorenoi V, Wichers C, Von Zur MA, Von Buren E, Brabant G: Age-related changes of serum sex hormones, insulin-like growth factor-I and sex-hormone binding globulin levels in men: cross-sectional data from a healthy male cohort. Clin Endocrinol (Oxf) 2000, 53:689-695.

43. Somel M, Khaitovich P, Bahn S, Paabo S, Lachmann M: Gene expression becomes heterogeneous with age. Curr Biol 2006, 16:R359-R360.

44. Abumaria N, Ribic A, Anacker C, Fuchs E, Flugge G: Stress upregulates TPHI but not TPH2 mRNA in the rat dorsal raphe nucleus: identification of two TPH2 mRNA splice variants. Cell Mol Neurobiol 2008, 28:331-342.

45. Boularand S, Darmon MC, Mallet J: The human tryptophan hydroxylase gene. An unusual splicing complexity in the 5'untranslated region. J Biol Chem 1995, 270:3748-3756.

46. Malhotra S, Sawhney G, Pandhi P: The therapeutic potential of melatonin: a review of the science. MedGenMed 2004, 6(2):46.

47. Barton AJ, Pearson RC, Najlerahim A, Harrison PJ: Pre- and postmortem influences on brain RNA. J Neurochem 1993, 6I:I-I I.

48. Preece $P$, Cairns NJ: Quantifying mRNA in postmortem human brain: influence of gender, age at death, postmortem interval, brain $\mathrm{pH}$, agonal state and inter-lobe mRNA variance. Brain Res Mol Brain Res 2003, I I 8:60-71.

49. Bahn S, Augood S), Ryan M, Standaert DG, Starkey M, Emson PC Gene expression profiling in the post-mortem human brainno cause for dismay. J Chem Neuroanat 200I, 22:79-94.

50. Tomita H, Vawter MP, Walsh DM, Evans SJ, Choudary PV, Li J, et al.: Effect of agonal and postmortem factors on gene expression profile: quality control in microarray analyses of postmortem human brain. Biol Psychiatry 2004, 55:346-352. 
5I. Bustin SA: Quantification of mRNA using real-time reverse transcription PCR (RT-PCR): trends and problems. J Mol Endocrinol 2002, 29:23-39.

52. Bustin SA, Benes V, Nolan T, Pfaffl MW: Quantitative real-time RT-PCR-a perspective. J Mol Endocrinol 2005, 34:597-60I.

53. Medhurst AD, Harrison DC, Read SJ, Campbell CA, Robbins MJ, Pangalos MN: The use of TaqMan RT-PCR assays for semiquantitative analysis of gene expression in CNS tissues and disease models. J Neurosci Methods 2000, 98:9-20.

54. Castensson A, Emilsson L, Sundberg R, Jazin E: Decrease of serotonin receptor $2 \mathrm{C}$ in schizophrenia brains identified by highresolution mRNA expression analysis. Biol Psychiatry 2003, 54:|2|2-|22|.

55. Vandesompele J, De Preter K, Pattyn F, Poppe B, Van Roy N, De Paepe A, et al: Accurate normalization of real-time quantitative RT-PCR data by geometric averaging of multiple internal control genes. Genome Biol 2002, 3:RESEARCH0034.

56. Livak KJ, Schmittgen TD: Analysis of relative gene expression data using real-time quantitative PCR and the 2(-Delta Delta C(T)) Method. Methods 200I, 25:402-408.

57. Bengtsson M, Stahlberg A, Rorsman P, Kubista M: Gene expression profiling in single cells from the pancreatic islets of Langerhans reveals lognormal distribution of mRNA levels. Genome Res 2005, 15:1388-1392.

Publish with Bio Med Central and every scientist can read your work free of charge

"BioMed Central will be the most significant development for disseminating the results of biomedical research in our lifetime. "

Sir Paul Nurse, Cancer Research UK

Your research papers will be:

- available free of charge to the entire biomedical community

- peer reviewed and published immediately upon acceptance

- cited in PubMed and archived on PubMed Central

- yours - you keep the copyright 